\title{
Skeletal and Metabolic Bone Disorders with special reference to African Americans
}

Prabir Mandal ${ }^{*}$, Noor Islam² and Anita Mandal ${ }^{3}$

${ }^{1}$ Department of Mathematics \& Sciences, 1740 Kings Road, Jacksonville, FL 32209, USA $\quad{ }^{2}$ Department of Social \& Behavioral Studies1740 Kings Road, Jacksonville, FL 32209, USA ${ }^{3}$ Department of General Studies 1740 Kings Road, Jacksonville, FL 32209, USA

*Corresponding author: Prabir Mandal, Department of Mathematics \& Sciences, 1740 Kings Road, Jacksonville, FL 32209, USA

Received date: March 26, 2021; Accepted date: April 02, 2021; published date: April 15, 2021

Citation: Prabir Mandal, Noor Islam, Anita Mandal.(2021) Skeletal and Metabolic Bone Disorders with special reference to African Americans J. Clinical Orthopaedics and Trauma Care, 3(1); DOI:10.31579/2694-0248/012

Copyright: (c) 2021 Prabir Mandal, This is an open access article distributed under the Creative Commons Attribution License, which permits unrestricted use, distribution, and reproduction in any medium, provided the original work is properly cited.

\begin{abstract}
The human skeleton is living tissue that is either growing or being renewed. Our understanding of the pathogenesis of bone disorders has progressed considerably over the past 37 years. A large number of genetic and developmental disorders affect the skeleton. Rare bone diseases account for 5\% of all birth defects. The skeletal dysplasias are inherited in an autosomal recessive, autosomal dominant, $\mathrm{X}$-linked recessive, and Xlinked dominant, and Y-linked manner.

Keywords: skeletal disorders; bone diseases; osteogenesis imperfecta; nosology; skeletal malformation syndrome
\end{abstract}

\section{Introduction}

The human body contains 206 bones and are living tissue. Older bone tissue is replaced with newly formed bone tissue in a process called remodeling. We commonly measure the condition of our bones by its density and our bone density peaks typically between the ages 25 and 30 . Thereafter, as we continue to age, our bones gradually lose density. Genetic disorders of the bones are a large group of rare clinically distinct and genetically varied conditions that affect fetal bones as they develop in the uterus. The skeletal rare diseases such as Osteogenesis imperfecta (OI; also known as brittle bone disease), juvenile Paget's disease or osteopetrosis (marble bone or stone bone disease) are the three of the more than 400 developmental abnormalities of the skeletal system.

Metabolic bone diseases are caused by congenital defects of bone cells or by factors that alter bone cell function. Many of these rare diseases are hereditary caused by genetic mutations that can be passed on to children of affected patients. Fibrous dysplasia (FD) is a rare bone disease characterized by replacement of the medullary cavity with fibrous tissue. Gorham's-Stout disease (GD), also known as vanishing bone disease, is a rare genetic disorder characterized by bone resorption and localized lymphangiogenic proliferation (Radhakrishnan and Rockson, 2008). Fibrodysplasia Ossificans Progressiva (FOP) is a rare disabling autosomal dominant disease that is characterized by heterotrophic ossification in the soft tissues following a simple injury (Kaplan et al., 2008). Melorheostosis is a rare genetic bone disease of unknown etiology in which patients exhibit bone dysplasia marked with benign sclerosis (Motimaya and Meyers, 2006). Multiple hereditary exostosis (MHE) is a genetic disorder marked by multiple cartilage-capped boney protuberances (osteochondromas) of the axial skeleton presenting usually before twelve years of age (Kivioja et al., 2000). Craniometaphyseal dysplasia (CMD) is an extremely rare genetic bone disorder characterized by overgrowth and progressive sclerosis of the craniofacial bones and flaring of the metaphyseal plates of femurs (Kirkpatrick, 1987; Cole and Cohen, 1988). Achondroplasia (chondrodysplasias) is a human bene genetic disorder of the growth plate and is the most common form of dwarfism (Horton et al., 2007). Hypophosphatasia (HPP) is an inherited metabolic bone disorder caused by genetic loss of function mutations of tissue non-specific alkaline phosphatase (Ramadza et al., 2009).

\section{Diagnosis}

The most common diseases or disorders that affect the bones are osteoporosis, Paget's disease, osteonecrosis, osteoarthritis, scoliosis and low bone density. Common symptoms include short bones of legs and/or arms, bowed or fractured bones, a small chest, abnormal ribs, duplication of fingers or toes etc. As the name implies, the disorders are due to genetic abnormalities. The cause may be linked to a dominant or recessive trait, or X-linked disorder, or a spontaneous gene mutation or fetal exposure to toxins or infections that interfere with normal skeletal development. Nosology Committee of the International Skeletal Dysplasia Society updated the tenth version of the Nosology which comprises 461 different diseases. Pathogenic variants affecting 437 different genes (92\%) of genetic skeletal disorders.

Conditions in which skeletal development is compromised result in misshapen bones, called skeletal dysplasias. It is a complex group of bone and cartilage disorders with strong clinical and genetic heterogeneity. In other cases, the organic component of the bone tissue is affected, leading to decreased bone strength, as in the case of osteogenesis imperfecta. Genetic defects can cause the bones to become very thick but malformed 
and brittle, as in the case of osteopetrosis. In some cases, the deposition of bone material is impaired, leading to bones that are too flexible and weak and are called rickets (which affects children) or osteomalacia (which affects adults). Patients with chronic renal disease are not only at risk of developing rickets and osteomalacia (Elder, 2002), but they are also at risk of a complex bone disease known as renal osteodystrophy (Cunningham et al., 2004). Paget's disease of bone (Siris and Roodman, 2003) is a progressive, often crippling disorder of bone remodeling that commonly involves the spine, pelvis, legs, or skull. In the 2015Nosology and Classification of Genetic Skeletal Disorders (GSDs) there were 436 GSDs with hundreds of causative genes (Bonafe et al., 2015). Fetal skeletal dysplasia (FSD) comprises a complex group of systemic bone and cartilage disorders (Waratani et al., 2020).

Osteoporosis are most commonly inherited in an autosomal dominant (AD) fashion but can be autosomal recessive (AR) or X-linked (XL) (Bollerslev et al., 2013). The AD, AR and XL forms of osteoporosis are predominantly caused by mutations in the CLCN7, TRIRG1 and IKBKG genes respectively. Between 85 and $90 \%$ cases are caused by mutations in COL1A1 and COL1A2 genes which code for type I collagen (Steiner et al., 2014). Hypophosphatasia (HPP) is multi-systemic metabolic dysplasia inherited in autosomal dominant or recessive fashion, caused by loss of funaction mutations in the ALPL gene which encodes the tissue non-specific alkaline phosphatase enzyme leading to defective bone mineralization (Whyte, 2017). XLH, also known as vitamin D-resistant rickets is the commonest heritable and non-nutritional form of rickets. $\mathrm{XLH}$ is X-linked dominant bone dysplasia caused by PHEX gene mutations. Fibrodysplasia Ossificans Progressiva is an extremely rare and severely disabling autosomal dominant condition, in which damaged fibrous tissue turns into bone. It is caused by activating mutations in the ACVR1 gene. The genetic basis of MHE has been identified due to mutations in the exostosin-1, EXT1 and EXT2 genes.

\section{African Americans}

The incidence of osteoporosis and related fractures in African American women is half that of Caucasian women. African American women who sustain osteoporosis-related fractures have increased disability and decreased survival. African American women begin menopause with higher bone mineral density (BMD) and have lower rates of women's bone loss after menopause, which account for their decreased incidence of osteoporosis and related fractures (Bohannon, 2009). Some studies in Caucasian and Asian women suggest that polymorphisms in the vitamin $\mathrm{D}$ receptor (VDR) gene are associated with $\mathrm{BMD}$ and the rate of postmenopausal bone loss. VDR gene polymorphisms are not associated with BMD or indices of bone turnover in the population of older African American women. DNA sequence variation in the VDR gene or a nearby locus may influence intestinal calcium transport and the rate of postmenopausal bone loss in African American women. African American children with Crohn's disease are more likely to have vitamin D deficiency compared to Caucasian with Crohn's disease, but have similar BMD. African Americans have a lower incidence of fractures than Caucasians, which has been attributed to a higher peak bone density in African Americans (Farmer et al., 1984; Jacobsen et al., 1990; Griffin et al., 1992). BMD is inversely related to abdominal visceral and subcutaneous adipose tissue (Katzmarzyk et al., 2012). It is becoming increasingly evident that suboptimal vitamin D (25OHD) serum levels are a common health problem. 25OHD insufficiency to be common in elderly African American women of low socioeconomic status.

\section{Prevention \& Treatment}

BMD is under genetic control. The ways to combat this natural loss of bone mass are medications e.g., vitamins and minerals, estrogen replacement therapy, strength-training and weight- bearing exercises. If Paget's disease of bone is diagnosed early, impact can be minimized.
Silencing of the dominant allele in OI would result in a milder phenotype and attempts using siRNAs (small interfering RNAs), shRNA (short hairpin RNA) and antisense oligodeoxyribonucleotides (ODNs) have been promising.

Treatments and outcomes depend on the type and severity of the skeletal disorder. Rickets and osteomalacia are relatively uncommon diseases in the United States, since they can generally be prevented by ensuring adequate levels of vitamin D. Bone marrow transplant (BMT) is frequently an effective form of treatment for the recessive infantile form of osteoporosis. Fetal stem cell transplants are not new, with similar treatments attempted since the 1980's and for other conditions (thalassemia, sickle cell, severe immune deficiency).

\section{Conclusion}

Osteoporosis is a major public health problem with low bone mass affecting half the women aged 50 years or older. Evidence from various studies has shown that higher body mass index is a protective factor for BMD. Though African American women are less likely to have low BMD than White women, the increase in BMD with body mineral index seen in Caucasians is not seen in African Americans. Several studies have documented relationships between adipose tissue and BMD. The explosion in molecular genetics has allowed for gene identification in more than two thirds of the skeletal dysplasias. Genetic counseling is recommended for affected individuals and their families. Should the trial of fetal stem cell transplants be successful it opens a whole new world for treatment of many different disorders. Thus the door is open for further technologies dealing with the root genetic change.

\section{References:}

1. Bohannon AD (2009): Osteoporosis and African American Women. J Women's Health Gender-Based Med, 8 (5): 609-615.

2. Bollerslev J, Henriksen K, Frost M, Brixen K, Van Hul W (2013): Autosomal dominant osteoporosis revisited: lessons from recent studies. Eur J Endocrinol, EJE-13.

3. Bonafe L, Cormier-Daire V, Hall C, Lachman R, Mortier G, Mundlos S, Nishimura G, Sangiorgi L, Savarirayan R, Sillence D, Spranger J, Superti-Furga A, Warman M and Unger S (2015): Nosology and Classification of genetic skeletal disorders: 2015 revision. Am J Med Gen Part A, 167A (12): 2869-2892.

4. Cole DE and Cohen MM (1988): A new look at craniometaphyseal dysplasia. Journal of Pediatrics, 112 (4): 577578.

5. Cunningham J, Sprague SM, Cannata-Andia J, Coco M, CohenSolal M, Fitzpatrick L, Goltzmann D, Lafage- Proust MH, Leonard M, Ott S, Rodriguez M, Stehman-Breen C, Stern P and Weisinger J (2004) Osteoporosis in chronic kidney disease. Am J Kidney Dis., 43 (3): 566-571.

6. Elder G (2002): Pathophysiology and recent advances in the management of renal osteodystrophy. J Bone Miner Res., 17 (12): 2094-2105.

7. Farmer ME, White LR, Brody JA and Bailey KR (1984): Race and sex differences in hip fracture incidence. Am J Public Health, 74: 1374-1380.

8. Griffin MR, Ray WA, Fought RL and Melton LJ III (1992): Black-white differences in fracture rtaes. Am J Epidemiol., 136: 1378-1385.

9. Horton WA, Hall JG and Hecht JT (2007): Achondroplasia. The Lancet, 370 (9582): 162-172.

10. Jacobsen SJ, Goldberg J, Miles TP, Brody JA, Stiers W and Rimm AA (1990): Hip fracture incidence among old and very old: a population-based study of 745,435 cases. Am J Public Health, 80: 871-873. 
11. Kaplan FS, Merrer ML, Glaser DL, Pignolo RJ, Goldsby R, Kitterman JA, Groppe J and Shore EM (2008): Fibrodysplasia ossificans progressive. Best Pract Res Clin Rheumatol, 22 (1): 191-205.

12. Katzmarzyk PT, Barreira TV, Harrington DM, Staiano AE, Heymsfield SB and Gimble JM (2012): Relationship between abdominal fat and bone mineral density in white and African American adults. Bone, 50 (2): 576-579.

13. Kirkpatrick DB (1987): Craniometaphyseal dysplasia. Surgical Neurology, 28 (3): 231.

14. Kivioja A, Ervasti H, Kinnunen J, Kaitila I, Wolf M and Bohling $\mathrm{T}$ (2000): Chondrosarcoma in a family with multiple hereditary exostoses. Journal of Bone and Joint Surgery, Series B, 82 (2): 261-266.

15. Motimaya AM and Meyers SP (2006): Melorheostosis involving the cervical and upper thoracic spine: radiographic, CT, and MR imaging findings. The American Journal of Neuroradiology, 27 (6): 1198-1200.
16. Radhakrishnan K and Rockson SG (2008): Gorham's disease: an osseous disease of lymphangiogenesis? Annals of the New York Academy of sciences, 1131: 203-205.

17. Ramadza DP, Stipoljev F, Sarnavka V, Begovic D, Potocki K, Fumic K, Mornet E and Baric I (2009): Hypophosphatasia: phenotypic variability and possible Croatian origin of the c.1402G>A mutation of TNSALP gene. Collegium Antropologicum, 33 (4): 1255-1258.

18. Siris ES and Roodman GD (2003): Paget's disease of bone. In: Favus MJ, editor. Primer on the metabolic bone diseases and disorders of mineral metabolism. 5. Washington, DC: American Society for Bone Mineral Research; pp. 495-506.

19. Steiner RD, Adsit J and Basel D (2014): COL1A1/2-related osteogenesis imperfect. Gene Reviews.

20. Waratani M, Ito F, Tanaka Y, Mabuchi A, Mori T and Kitawaki J (2020): Prenatal diagnosis of fetal skeletal dysplasia using 3 dimensional computed tomography: a prospective study. BMC Musculoskelet Disord, 21 (1): 662.

21. Whyte MP (2017): Hypophosphatasia: an overview for 2017. Bone, 102: 15

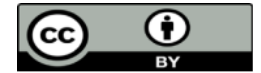

This work is licensed under Creative Commons Attribution 4.0 License

\section{To Submit Your Article Click Here: Submit Manuscript}

DOI: $10.31579 / 2694-0248 / 012$
Ready to submit your research? Choose Auctores and benefit from:

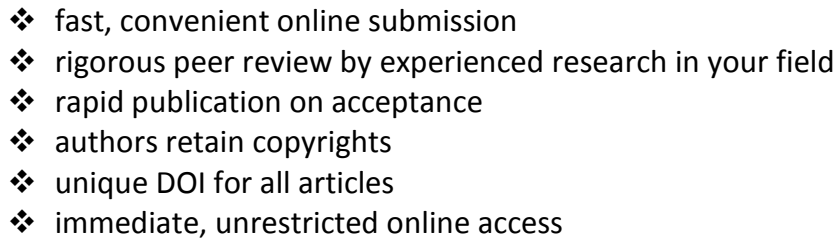

At Auctores, research is always in progress.

Learn more www.auctoresonline.org/journals/clinical-orthopaedics-andtrauma-care 